Formatif: Jurnal Ilmiah Pendidikan MIPA

Vol. 9, No. 1, Maret 2019, pp. 59-70

p-ISSN: 2088-351X

e-ISSN: 2502-5457

DOI: http://dx.doi.org/10.30998/formatif.v9i1.2884

\title{
The Validity and Students Response toward Coordination System Teaching Material Oriented Guided Inquiry
}

\author{
Validitas dan Respon Siswa terhadap Bahan Ajar Sistem Koordinasi Berorientasi \\ Inkuiri Terbimbing
}

\author{
Jan Hendrik Nunaki \\ Universitas Papua \\ Yelsi Patiung \\ Universitas Papua
}

Novri Youla Kandowangko

Universitas Negeri Gorontalo

Elya Nusantari

Universitas Negeri Gorontalo

Insar Damopolii *)

Universitas Papua

Received: September 29, 2018

Revised: November 11, 2018

Accepted: December 06, 2018

\begin{abstract}
Learning in the 21 st-century class expects teachers to apply learning that invites students to conduct investigations. Guided inquiry learning is an example of learning that can train students' investigative abilities. This study aimed to analyze the validity and response of students on the used of coordination system teaching materials oriented guided inquiry. This research was part of research and development research that adapts the 4D model. The research subjects were 17 students of XI Grade SMA YPK Oikoumene Manokwari. Three experts and three practitioners were used for the validation process and a focus group discussion (FGD). Validation results showed that the coordination system teaching material oriented guided inquiry was valid and can be used for testing in the classroom. The response of students in the small group trial showed that learning could improve their motivation, comprehension, skill and interested in biology teaching. Their response is excellent. It can be concluded that the coordination system for teaching material oriented guided inquiry can be using for the next stage of testing to see its effectiveness. The effectiveness of learning in the next trial will be carried out in the future.
\end{abstract}

Keywords: Coordination system, inquiry learning, student response, teaching material, validity

(*) Corresponding Author: $\quad$ i.damopoli@unipa.ac.id

How to Cite: Nunaki, J.H., Patiung, Y., Kandowangko, N.Y., Nusantari, E., \& Damopolii, I. (2019). The validity and students response toward coordination system teaching material oriented guided inquiry. Formatif: Jurnal Ilmiah Pendidikan MIPA, 9 (1): 59-70. http://dx.doi.org/10.30998/formatif.v9i1.2884 
Formatif: Jurnal Ilmiah Pendidikan MIPA

Vol. 9, No. 1, Maret 2019, pp. 59-70

p-ISSN: 2088-351X

e-ISSN: 2502-5457

DOI: http://dx.doi.org/10.30998/formatif.v9i1.2884

\section{PENDAHULUAN}

Pembelajaran merupakan suatu proses yang diselenggarakan oleh guru untuk membelajarkan peserta didik, bagaimana belajar memperoleh dan memproses pengetahuan, keterampilan, dan sikap. Dalam pembelajaran seorang guru membutuhkan sumber belajar untuk menunjang kegiatan belajar mengajar. Sumber belajar adalah segala tempat atau lingkungan sekitar, benda, dan orang yang memiliki informasi serta dapat digunakan sebagai wahana bagi peserta didik untuk melakukan proses perubahan tingkah laku. Hal ini, mengindikasikan guru dan peserta didik harus memenuhi persyaratan, baik dalam pengetahuan, kemampuan sikap, nilai serta sifat-sifat pribadi, dimaksudkan agar proses pembelajaran dapat terlaksana dengan efisien dan efektif.

Hasil observasi di sekolah menunjukkan bahwa proses pembelajaran biologi yang berlangsung di kelas terbilang masih sangat rendah, perangkat pembelajaran yang digunakan oleh guru juga masih sangat terbatas, serta guru yang masih menerapkan pembelajaran konvensional khususnya di kelas XI MIA. Proses pembelajaran abad 21 akan berjalan baik jika didukung oleh bahan ajar yang membawa siswa ke dalam situasi kehidupan nyata (Damopolii, Nunaki, Nusantari, \& Kandowangko, 2018). Hasil penelitian beberapa peneliti sebelumnya menunjukkan bahwa bahan ajar berbasis inkuiri yang dikembangkan adalah valid secara teoritik dan perlu diuji coba dalam kelas terbatas (Ariyanti, Fajaroh, \& Sutrisno, 2013; Lepiyanto \& Pratiwi, 2015; Lesmana, Lestari, \& others, 2015). Proses pembelajaran yang dilaksanakan masih didominasi oleh guru dan tidak memberikan kesempatan bagi Peserta didik untuk berkembang secara mandiri melalui proses pemikirannya sendiri. Hal ini, membuat peserta didik sering merasa bosan dalam mengikuti pelajaran. Selain itu pembelajaran biologi di Indonesia belum menumbuhkan proses penyidikan pada siswa (Suwono, Susanti, \& Lestari, 2017). Guru dalam pembelajaran sains seperti pada mata pelajaran biologi perlu menggunakan strategi yang berbeda sesuai dengan hasil evaluasi terhadap pembelajaran yang telah dilaksanakan, kebutuhan siswa, keberagaman kelas, dan memahami berbagai jenis pembelajaran (Lameras et al., 2014).

Proses belajar mengajar dengan menggunakan metode yang didominasi oleh guru memberi celah kepada peserta didik untuk melakukan D3: datang, duduk, diam. Peserta didiklah yang harus diberi ruang untuk menyerap, mengerti, dan merespon setiap bagian dari materi yang disampaikan. Guru harus berlomba dengan dirinya sendiri untuk menikmati dan mendapat hasil maksimal dari proses belajar yang dilakukan, bukan hanya sekedar berlomba untuk menyelesaikan materi pelajaran tepat sebelum ujian. Meskipun demikian, hal ini bukan berarti bahwa proses pembelajaran boleh terhambat asalkan peserta didik senang, karena setiap proses belajar memiliki durasi waktu yang harus tetap dipatuhi. Pemahanam siswa terhadap suatu materi dapat ditemukan melalui interaksi siswa dengan lingkungan (Loyens \& Gijbels, 2008).

Ketentuan kurikulum mata pelajaran biologi di Indonesia adalah peningkatan pemahaman konsep, sikap, pemecahan masalah, dan berbagai keterampilan seperti keterampilan berpikir, keterampilan proses sains, keterampilan metakognitif, dan keterampilan lainnya. Untuk melatih hal itu, maka pembelajaran harus diadaptasikan pada teori konstruktivisme. Pendekatan konstruktivisme didasarkan pada asumsi bahwa mengumpulkan pengetahuan adalah proses individual, dimana belajar dicapai dengan membangun konsep baru melalui integrasi pengetahuan sebelumnya dengan pengetahuan baru dan bukan hanya dengan menambahkan pengetahuan baru ke pengetahuan yang sudah ada (Moustafa, Ben-Zvi-Assaraf, \& Eshach, 2013).

Salah satu pembelajaran yang mengikuti teori konstruktivisme adalah pembelajaran berbasis inkuiri. Pembelajaran inkuiri telah diimplementasikan di sekolah menengah 


\section{Formatif: Jurnal Ilmiah Pendidikan MIPA}

Vol. 9, No. 1, Maret 2019, pp. 59-70

p-ISSN: 2088-351X

e-ISSN: $2502-5457$

DOI: http://dx.doi.org/10.30998/formatif.v9i1.2884

pertama dan sekolah mengah atas semenjak abad terakhir (Lati, Supasorn, \& Promarak, 2012). Banyak pendidik percaya bahwa pembelajaran inkuiri efisien dalam mengembangkan keterampilan inkuiri dan keterampilan berpikir kritis (Sadeh \& Zion, 2009). Siswa diberikan kesempatan untuk mengamati serta mengeksplorasi (Ango, 2002). Di seluruh dunia, inquiri dalam pembelajaran sains menjadi topik penting (Yang, Park, Shin, \& Lim, 2017). Beberapa penelitian menyimpulkan bahwa pembelajaran inkuiri mempunyai pengaruh terhadap hasil belajar, keterampilan proses sains, keterampilan berpikir kritis, dan sikap ilmiah (Damopolii, Hasan, \& Kandowangko, 2015; Damopolii, Yohanita, Nurhidaya, \& Murtijani, 2018; Hadi, Susantin, \& Agustini, 2018; Isrianto, 2016; Mayasari, Raharjo, \& Supardi, 2018; Nisa, Koestiari, Habibbulloh, \& Jatmiko, 2018). Pembelajaran inkuiri efektif untuk semua tipe siswa, dari siswa yang terlemah sampai terpintar termasuk di dalamnya siswa yang berbakat, laki-laki dan perempuan, serta semua jenang umur siswa (Trna, Trnova, \& Sibor, 2012).

Pembelajaran adalah suatu sistem dimana di dalamnya terdapat berbagai komponen yang menyatu untuk terciptanya pembelajaran yang berkualitas. Salah satu komponen yang ada adalah bahan ajar. Guru dapat sedini mungkin untuk membuat perencanaan yang matang dalam meningkatkan pembelajaran bagi siswanya untuk meningkatkan pembelajaran (Damopolii, Nunaki, \& Supriyadi, 2018). Lingkungan pembelajaran pada bidang sains seperti mata pelajaran biologi sangat dipengaruhi oleh pembelajaran berbasis inkuiri (Wagh, Cook-Whitt, \& Wilensky, 2017).

Berdasarkan hasil observasi dan beberapa kajian penelitian sebelumnya, maka peneliti tertarik untuk mengembangkan bahan ajar berbasis inkuiri terbimbing. Pembelajaran inkuiri disarankan dalam kelas abad 21. Penggunaan inkuiri dalam level inkuiri terbimbing, karena dikondisikan dengan keadaan siswa. Proses validasi dari bahan ajar biologi yang dikembangkan akan didiskusikan.

\section{METODE}

Jenis penelitian yang digunakan dalam penelitian ini adalah penelitian pengembangan (Research and Development) dengan melakukan uji coba produk. Model pengembangan yang digunakan adalah 4D (Thiagarajan, Semmel, \& Semmel, 1974). Perangkat yang dikembangkan dalam penelitian ini adalah berupa rencana pelaksanaan pembelajaran (RPP), lembar kerja peserta didik (LKPD), bahan ajar peserta didik (BAS) berbasis inkuiri pada topik materi sistem koordinasi (sampel bagian bahan ajar pada Gambar 1-4), tes hasil belajar dan tes keterampilan proses sains. Pada artikel ini, kajian terbatas pada hasil validasi dan respon siswa pada uji coba terbatas. Subjek penelitian adalah siswa kelas XI IPA SMA Oikoumene Manokwari.

Instrumen validasi berupa lembar validasi perangkat pembelajaran digunakan untuk memvalidasi perangkat pembelajaran yang akan digunakan dalam tahap implementasi yang terdiri atas rencana pelaksanaan pembelajaran (RPP), lembar kerja peserta didik (LKPD), bahan ajar peserta didik (BAS), tes hasil belajar, dan tes keterampilan proses sains. Lembar validasi ini diisi oleh tiga orang ahli dan tiga orang praktisi (guru sekolah).

Analisis validitas untuk setiap item pernyataan dengan menggunakan persamaan CVR (Content Validity Ratio). Penilaian dikatagorikan valid jika CVR berada pada kisaran nilai 0,7 s.d 1. Untuk menghitung CVR digunakan rumus menurut Lawshe, (1975) yang dimodifikasi oleh Polit, Beck, \& Owen, (2007) untuk CVR dengan jumlah validator 6. sebagai berikut, 
Formatif: Jurnal Ilmiah Pendidikan MIPA

Vol. 9, No. 1, Maret 2019, pp. 59-70

p-ISSN: 2088-351X

e-ISSN: 2502-5457

DOI: http://dx.doi.org/10.30998/formatif.v9i1.2884

$$
\mathrm{CVR}=\frac{\mathrm{n}_{\mathrm{e}}-\frac{\mathrm{N}}{2}}{\frac{\mathrm{N}}{2}}
$$

Keterangan:

$\mathrm{n}_{\mathrm{e}}$ : Banyaknya validator yang memberikan nilai esensial (3 dan 4)

$\mathrm{N}$ : Jumlah validator

Respon siswa terhadap pembelajaran berbasis inkuiri dihitung dengan rumus sebagai berikut,

$$
\begin{aligned}
& \mathrm{PSR}=\frac{\sum \mathrm{X}}{\sum \mathrm{Xi}} \mathrm{X} 100 \% \\
& \begin{array}{ll}
\mathrm{PSR} & =\text { persentase respon siswa } \\
\sum \mathrm{X} & =\text { Jumlah skor yang diperoleh } \\
\sum \mathrm{X}_{\mathrm{i}} & =\text { Jumlah skor total }
\end{array}
\end{aligned}
$$

Tabel 1. Kriteria Respon Siswa

\begin{tabular}{cc}
\hline Persentase & Kriteria \\
\hline $85-100$ & Sangat Baik \\
$70-84$ & Baik \\
$55-69$ & Cukup \\
$40-54$ & Kurang \\
$<40$ & Sangat Kurang \\
\hline
\end{tabular}

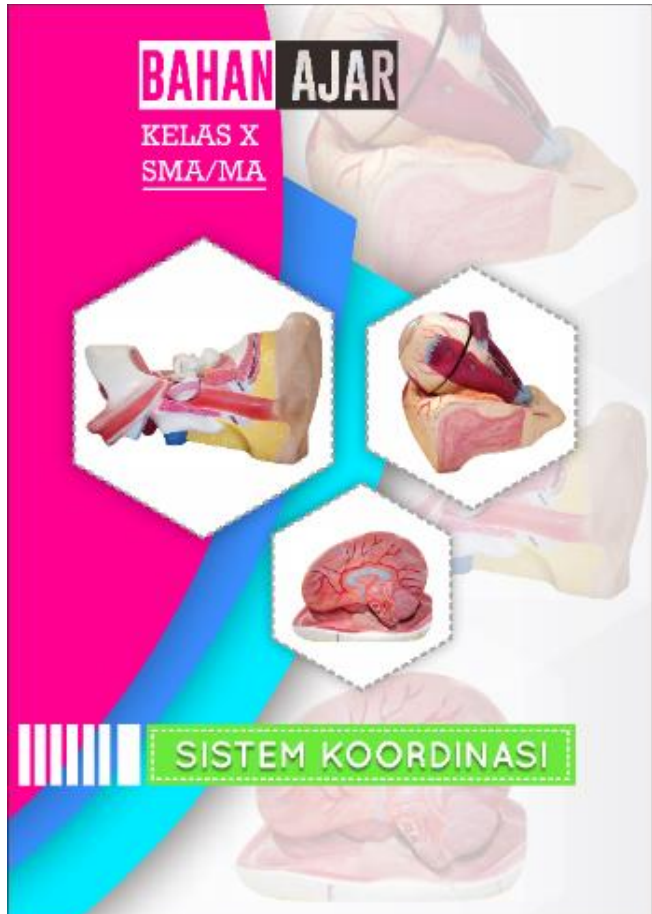

Gambar 1. Sampul Depan Bahan Ajar

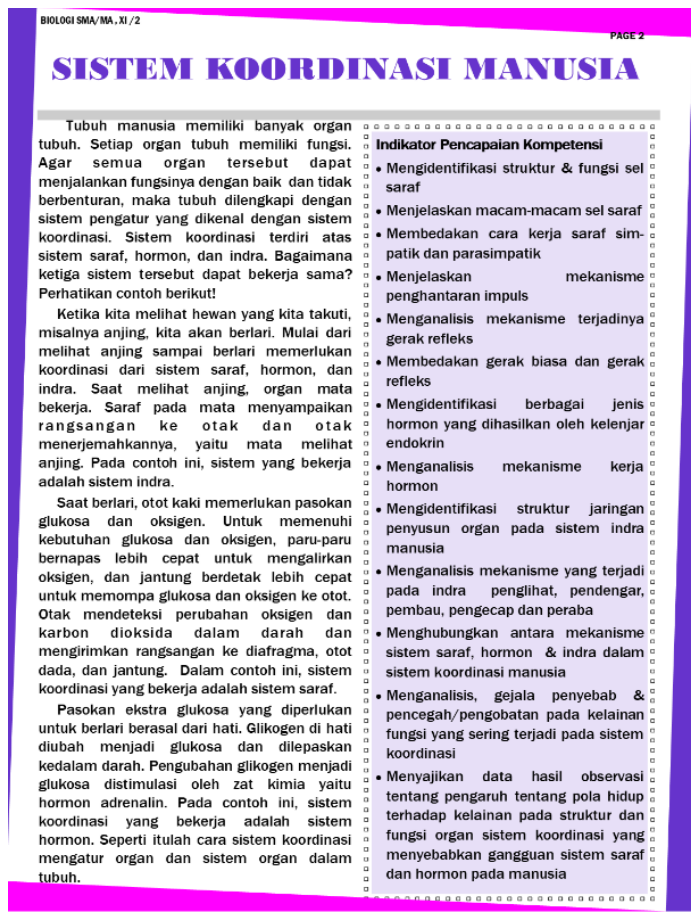

Gambar 2. Halaman Awal Bahan Ajar 
Formatif: Jurnal Ilmiah Pendidikan MIPA

Vol. 9, No. 1, Maret 2019, pp. 59-70

p-ISSN: 2088-351X

e-ISSN: 2502-5457

DOI: http://dx.doi.org/10.30998/formatif.v9i1.2884

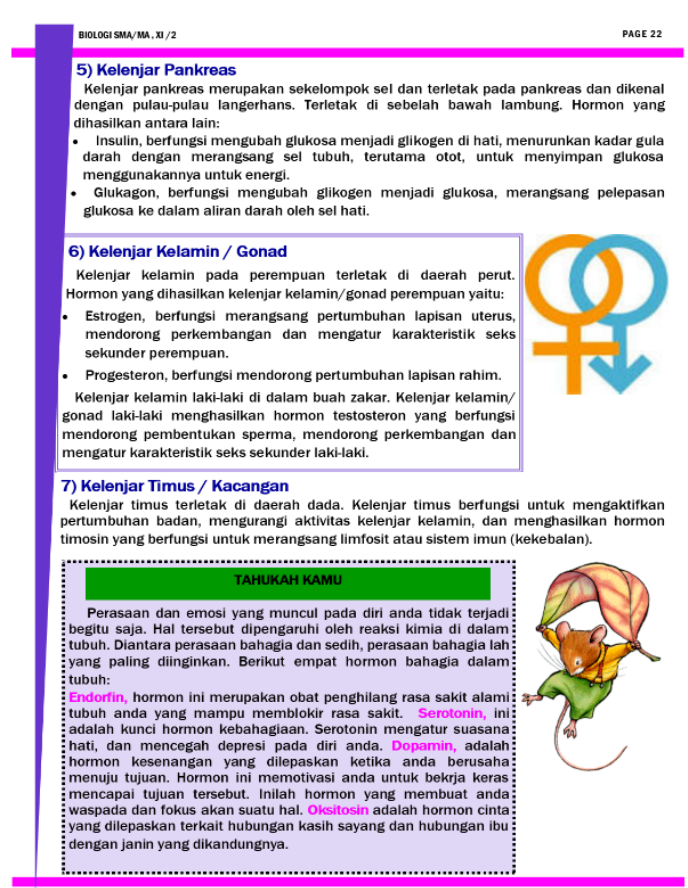

Gambar 3. Contoh Konten Materi

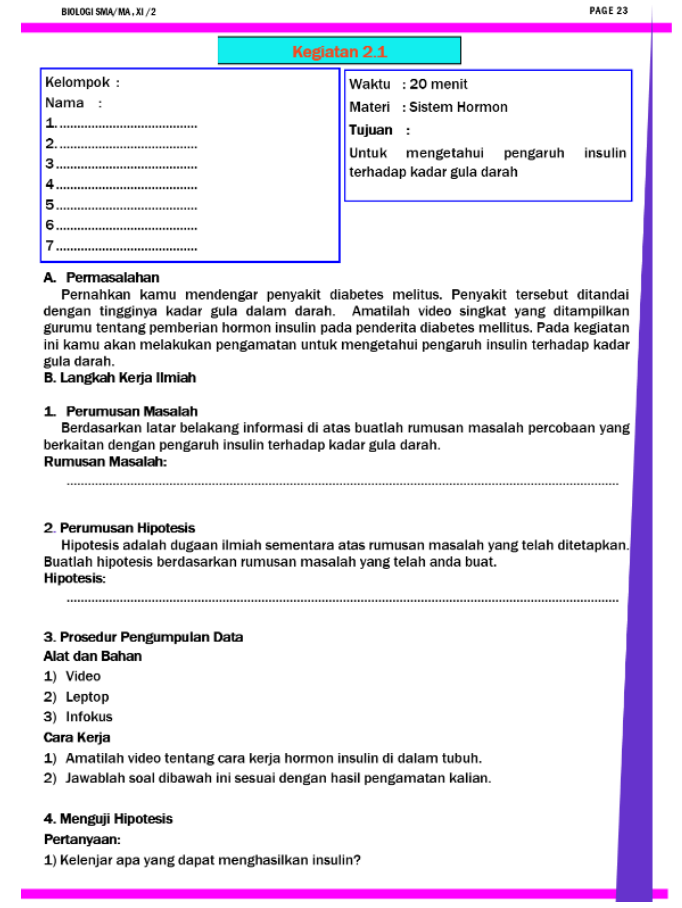

Gambar 4. Bagian Inkuiri dalam Bahan Ajar

\section{HASIL DAN PEMBAHASAN}

\section{Hasil}

Hasil penelitian yang disajikan adalah berupa hasil validasi dari ahli dan praktisi, dan hasil revisi dari penulis. Selain itu ditampilkan juga respon siswa terhadap pembelajaran berbasis inkuiri.

Tabel 2. Hasil Validasi

\begin{tabular}{llcc}
\hline No & \multicolumn{1}{c}{ Perangkat Pembelajaran } & CVR & Kriteria \\
\hline 1. & Rencana Pelaksanaan Pembelajaran & 1 & Valid \\
2. & Bahan Ajar & 1 & Valid \\
3. & Lembar Kerja Peserta didik (LKPD) & 1 & Valid \\
4. & Tes Hasil Belajar (THB) & 1 & Valid \\
5. & Tes Keterampilan Proses Sains & 1 & Valid \\
\hline
\end{tabular}

Berdasarkan keterangan pada Tabel 2 semua perangkat pembelajaran dinyatakan valid dan dapat digunakan dalam proses pembelajaran, tetapi dengan revisi kecil sebelum digunakan dalam uji coba kelas terbatas. Hasil validasi ini digunakan untuk mengukur validitas perangkat pembelajaran.

\section{Hasil Revisi (Perbaikan Perangkat Pembelajaran).}

Setelah perangkat pembelajaran serta instrumennya dinyatakan valid dengan syarat perangkat dapat diterapkan apabila sudah dilakukan revisi kecil maka dilakukan revisi atau perbaikan berdasarkan saran dari ahli sebagai berikut, 


\section{Formatif: Jurnal Ilmiah Pendidikan MIPA}

Vol. 9, No. 1, Maret 2019, pp. 59-70

p-ISSN: 2088-351X

e-ISSN: 2502-5457

DOI: http://dx.doi.org/10.30998/formatif.v9i1.2884

\section{1) Hasil revisi Rencana Pelakasanaan Pembelajaran (RPP)}

Beberapa saran dari ahli untuk perbaikan RPP antara lain sebagai berikut,

(1) Pengunaan bahasa yang jelas agar mudah dimengerti, (2) Dalam penyususnan RPP pada IPK untuk pertemuan ke 1, 2, dan 3 disarankan untuk menunjukkan $\mathrm{C} 1, \mathrm{C} 2, \mathrm{C} 3$, dan seterusnya sesuai dengan kompetensi dasar, (3) RPP harus disesuaikan lagi dengan bahan ajar yang telah dibuat, Hasil revisi RPP adalah, (1) Penggunaan bahasa sudah diperjelas dengan menggunakan kalimat yang mudah dipahami, (2) Dalam penyusunan RPP pada indikator pencapaian kompetensi (IPK) untuk pertemuan ke 1, 2, dan 3 telah ditunjukkan C1, C2, C3, dan seterusnya yang sesuai dengan kompetensi dasar, (3) RPP telah disesuaikan dengan bahan ajar yang telah dibuat.

\section{2) Hasil Revisi Bahan Ajar dan LKPD}

Beberapa saran dari ahli untuk perbaikan Bahan Ajar dan LKPD adalah sebagai berikut, (1) Tidak perlu menambahkan sekilan info di bagian tepi jika hanya berada di satu lembar kertas, sedangkan bagian lainnya tidak diberi sekilas info, (2) Koordinasi antara tiga sistem sebaiknya menggunakan contoh pada kehidupan sehari-hari, (3) Pada bahan ajar model inkuirinya harus lebih terlihat, (4) Sebaiknya di setiap subbab harus ada indikatornya, (5) Materi pada bahan ajar sebaiknya dibuat menjadi bagian-bagian (bagian saraf, bagian hormon, bagian indra, dan hubungan antara saraf, hormon, serta indra), 6) Pertanyaan-pertanyaan yang ada di dalam lembar kerja peserta didik diganti menjadi pertanyaan-pertanyaan yang dapat membuat peserta didik lebih berpikir kritis. Hasil revisi bahan ajar dan LKPD adalah, (1) Kata sekilas info telah dihilangkan dari bahan ajar, (2) Koordinasi antara tiga sistem telah menggunakan contoh pada kehidupan sehari-hari, (3) Pada bahan ajar inkuirinya sudah lebih terlihat, (4) Pada setiap subbab telah diberikan indikator, (5) Materi pada bahan ajar telah dibuat menjadi bagian-bagian (bagian saraf, hormon, indra, dan saraf, hormon, dan indra), (6) Pertanyaan-pertanyaan yang ada di LKPD telah diganti menjadi pertanyaan-pertanyaan yang dapat membuat peserta didik lebih berpikir kritis.

Tabel 3. Respon Siswa terhadap Pembelajaran Berbasis Inkuiri

\begin{tabular}{llcc}
\hline No & \multicolumn{1}{c}{ Pernyataan } & \% Respon & Kriteria \\
\hline 1 & $\begin{array}{l}\text { Menggunakan pembelajaran inkuiri pada } \\
\text { materi sistem koordinasi adalah bermanfaat }\end{array}$ & 88,24 & Sangat baik \\
2 & $\begin{array}{l}\text { Belajar biologi berbasis inkuiri membuat } \\
\text { saya lebih terampil dalam percobaan }\end{array}$ & 85,29 & Sangat baik \\
3 & $\begin{array}{l}\text { Belajar biologi berbasis inkuiri membuat } \\
\text { saya terampil berpikir }\end{array}$ & 80,88 & Baik \\
4 & $\begin{array}{l}\text { Belajar biologi dengan perangkat } \\
\text { pembelajaran (bahan ajar dan LKPD ) } \\
\text { berbasis inkuiri membuat saya terampil } \\
\text { merumuskan masalah dengan baik. }\end{array}$ & 88,24 & Sangat baik \\
5 & $\begin{array}{l}\text { Belajar biologi dengan perangkat } \\
\text { pembelajaran (bahan ajar dan LKPD) } \\
\text { berbasis inkuiri membuat saya terampil } \\
\text { merumuskan hipotesis dengan baik. }\end{array}$ & 86,76 & Sangat baik \\
Belajar biologi berbasis inkuiri membuat \\
saya terampil dalam membuat simpulan. \\
Belajar biologi mendorong saya untuk \\
memecahkan masalah dengan menemukan \\
ide-ide baru.
\end{tabular}


Formatif: Jurnal Ilmiah Pendidikan MIPA

Vol. 9, No. 1, Maret 2019, pp. 59-70

p-ISSN: 2088-351X

e-ISSN: 2502-5457

DOI: http://dx.doi.org/10.30998/formatif.v9i1.2884

\begin{tabular}{clcc}
\hline 8 & $\begin{array}{l}\text { Belajar biologi membuat saya lebih } \\
\text { memahami materi. }\end{array}$ & 85,29 & Sangat baik \\
9 & $\begin{array}{l}\text { Belajar biologi berbasis inkuiri membuat } \\
\text { saya lebih termotivasi. }\end{array}$ & 80,88 & Baik \\
10 & $\begin{array}{l}\text { Belajar biologi berbasis inkuri melatih saya } \\
\text { untuk bisa mengemukakan pendapat. }\end{array}$ & 92,65 & Sangat baik \\
11 & $\begin{array}{l}\text { Belajar biologi berbasis inkuiri membuat } \\
\text { saya lebih aktif dalam proses pembelajaran. } \\
\text { Belajar biologi berbasis inkuiri membuat } \\
\text { pelajaran biologi lebih menarik untuk } \\
\text { dipelajari. }\end{array}$ & 91,18 & Sangat baik \\
\hline & Rata-rata Total & $\mathbf{8 7 , 3 8}$ & Sangat baik \\
\hline
\end{tabular}

Berdasarkan data pada Tabel 3 menunjukkan bahwa respon siswa terhadap pembelajaran berbasis inkuiri pada materi sistem koordinasi mendapat respon yang sangat baik dari siswa.

\section{Pembahasan}

Hasil validasi RPP memperoleh nilai kevalidan 1 (Valid). RPP yang dihasilkan terdiri dari 4 kali pertemuan. RPP ini dikembangkan untuk melatih keterampialn berpikir, metakognitif, dan keterampilan proses sains peserta didik melalui kegiatan percobaan serta pertanyaan-pertanyaan dalam proses pembelajaran yang terdapat dalam LKPD berbasis inkuiri. Hasil validasi bahan ajar dengan nilai kevalidan 1 (valid). Bahan ajar merupakan bagian yang sangat penting dari suatu proses pembelajaran, sehingga bahan ajar yang digunakan dalam penelitian ini dikembangkan sedemikian rupa agar peserta didik menjadi lebih aktif dalam proses pembelajaran.

Lembar kerja peserta didik memperoleh nilai kevalidan 1 (valid). Lembar kerja peserta didik yang dihasilkan merupakan panduan bagi peserta didik untuk melakukan kegiatan penyelidikan untuk memecahkan masalah dalam pembelajaran pada pokok bahasan sistem koordinasi. Seperti halnya bahan ajar yang telah dikembangkan, lembar kerja peserta didik juga dikembangkan dengan berorientasi pada inkuiri, sehingga terlihat lebih menarik. Peserta didik menjadi lebih aktif dan termotivasi untuk melakukan setiap percobaan yang ada pada LKPD, maupun menjawab setiap pertanyaan yang terdapat pada LKPD. Tes hasil belajar dengan nilai kevalidan 1 (valid), digunakan untuk mengetahui sejauh mana tingkat pemahaman peserta didik terhadap materi yang telah diajarkan. Tes keterampilan proses sains dengan nilai kevalidan 1 (valid) digunakan untuk melihat keterampilan proses sains peserta didik. Berdasarkan hasil validasi perangkat pembelajaran yang telah dipaparkan maka perangkat pembelajaran yang telah dikembangkan dinyatakan valid serta dapat diujicobakan pada kelas terbatas. Hasil penelitian yang diperoleh sejalan dengan penelitian sebelumnya yang menemukan bahwa bahan ajar berbasis inkuiri yang dikembangkan adalah valid, tetapi perlu dilakukan uji coba terbatas (Ariyanti et al., 2013).

Berdasarkan hasil analisis terhadap angket respon peserta didik pada uji coba terbatas, rata-rata peserta didik memberikan penilaian sangat baik. Fadilah, Kardi, \& Supardi, (2017) mengemukakan bahwa untuk mengetahui respon siswa pada pembelajaran berbasis inkuiri, maka digunakanlah angket. Peserta didik memberikan respon di atas 80 $\%$, yang artinya peserta didik memiliki tanggapan/respon yang baik terhadap proses pembelajaran dengan menggunakan bahan ajar berbasis inkuiri. Peserta didik menjadi lebih antusias dalam proses pembelajaran. Proses pembelajaran berbasis inkuiri melibatkan peserta didik secara langsung untuk melakukan percobaan-percobaan yang berhubungan 
Formatif: Jurnal Ilmiah Pendidikan MIPA

Vol. 9, No. 1, Maret 2019, pp. 59-70

p-ISSN: 2088-351X

e-ISSN: 2502-5457

DOI: http://dx.doi.org/10.30998/formatif.v9i1.2884

langsung dengan materi yang diajarkan, sehingga mereka merasa lebih tertarik untuk belajar serta materi yang diberikan lebih mudah untuk dipahami.

Berdasarkan hasil penelitian yang telah dilakukan maka perangkat pembelajaran yang dikembangkan dan telah melalui tahap uji coba dapat bermanfaat bagi siswa dengan respon pada pernyataan 1 sebesar $88,24 \%$, melatih keterampilan berpikir dengan rata-rata respon pada pernyataan 3 dan 7 sebesar 86,03\%, membuat siswa dapat lebih memahami materi dengan respon pada pernyataan 8 sebesar $85,29 \%$, siswa menjadi aktif dengan respon pada pernyataan 11 sebesar $91,18 \%$, termotivasi dengan respon pada pernyataan 9 sebesar 80,88 \%, melatih keterampilan proses siswa dengan rata-rata respon pada pernyataan 2, 4, 5, 6 dan 10 sebesar 87,94\%, dan tertatik untuk belajar biologi dengan respon pada pernyataan 12 sebesar 91,18. Hasil pengembangan bahan ajar dan respon siswa yang baik sejalan dengan penelitian Damopolii, Nunaki, Nusantari, et al., (2018) yang menemukan bahwa bahan ajar ekosistem yang dikembangkan layak digunakan dalam pembelajaran biologi dengan respon siswa pada kelas terbatas adalah sangat baik. Lingkungan belajar, gaya pengajaran guru, dan proses pemilihan pembelajaran tidak sengaja menyebabkan hilangnya siswa yang mampu dan tertarik untuk belajar (Tanner \& Allen, 2004). Pembelajaran berbasis inkuiri dilengkapi dengan bahan ajar berorientasi inkuiri mengubah suasana pembelajaran menjadi lebih aktif dan menyenangkan, sehingga siswa menjadi tertarik untuk belajar. Disisi lain, pembelajaran berbasis konstruktivisme seperti inkuiri memiliki hubungan yang kuat dengan motivasi belajar, (Boddy, Watson, \& Aubusson, 2003), dan membantu siswa terlibat dalam pemikiran dan pembelajaran tingkat tinggi (Ash-Shiddieqy, Suparmi, \& Sunarno, 2018; Gillies, Nichols, Burgh, \& Haynes, 2012). Pada penelitian lain juga menemukan bahwa implementasi pembelajaran inkuiri pada mata pelajaran biologi menumbuhkan kemampuan berpikir, dan dapat mengubah pembelajaran pasif menjadi pembelajaran aktif (Adnan \& Bahri, 2018), serta meningkatkan pemahaman dan keterampilan proses sains siswa (Rukmana, 2018).

Kegiatan pembelajaran yang berbasis inkuiri membuat siswa terlatih untuk melakukan kegiatan penyelidikan, belajar membuat dugaan sementara, sampai membelajarkan mereka membuat simpulan dari hasil percobaan mereka. Dalam kegiatan yang dilaksanakan misalnya, siswa mengajukan hipotesis tentang hubungan antar indra manusia. Siswa diberikan masalah, kemudian siswa membuat suatu rumusan masalah dan mengajukan hipotesis dibimbing oleh guru. Di sinilah pembelajaran berbasis inkuiri terbimbing terlihat berbeda dari pembelajaran inkuri lainnya.

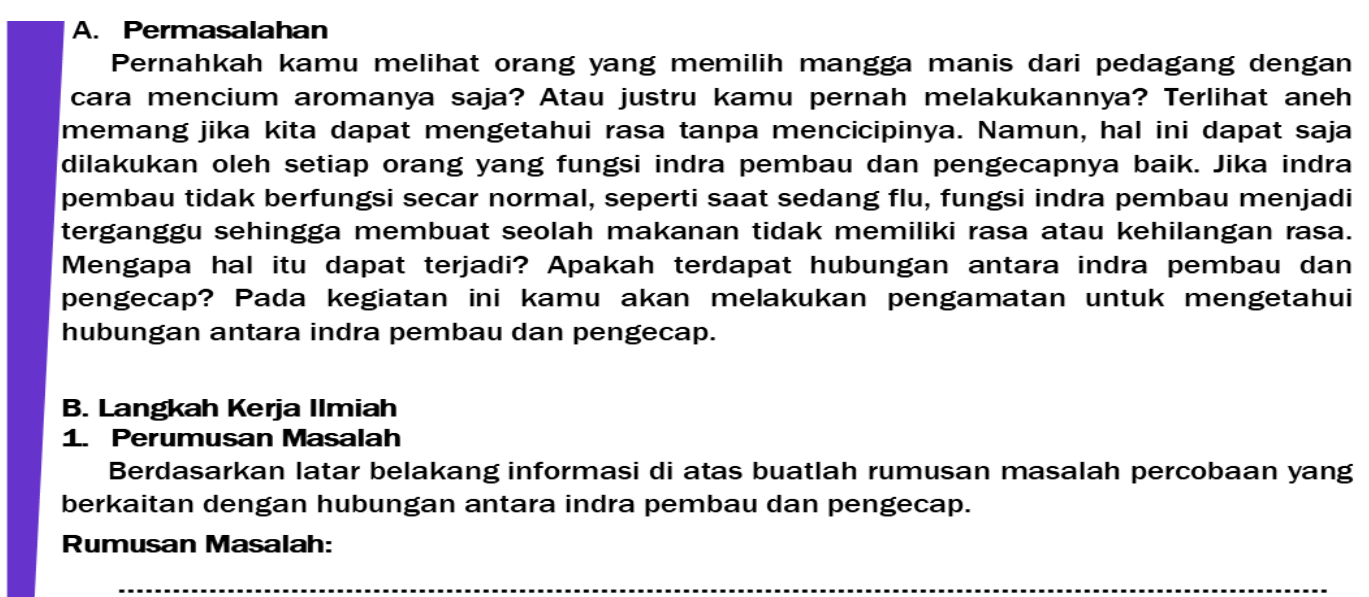

Gambar 5. Contoh Permasalahan yang Diberikan dan Menuliskan Rumusan Masalah 


\section{Formatif: Jurnal Ilmiah Pendidikan MIPA}

Vol. 9, No. 1, Maret 2019, pp. 59-70

p-ISSN: 2088-351X

e-ISSN: 2502-5457

DOI: http://dx.doi.org/10.30998/formatif.v9i1.2884

Ketika pembelajaran, siswa terlihat termotivasi untuk melakukan praktikum berbasis inkuiri. Pada kegiatan praktikum, motivasi belajar berkontribusi terhadap siswa dalam mengeksplorasi kemampuannya untuk pemecahan masalah (Kahar, 2018). Mereka terlatih keterampilannya dan berpikir dengan baik untuk mencari jawaban sampai membuat simpulan hasil penyelidikan mereka. Hasil dari validasi dan respon yang sangat baik dari siswa, menunjukkan bahwa bahan ajar materi sistem koordinasi serta intrumen lainnya layak untuk diujicobakan di tahap selanjutnya.

\section{PENUTUP}

Berdasarkan hasil penelitian dan diskusi pada pembahasan, peneliti menyimpulkan bahwa bahan ajar materi sistem koordinasi dan perangkat lainnya seperti RPP, LKS, tes hasil belajar, dan tes keterampilan proses sains adalah valid yang menandakan layak secara teoritik untuk digunakan dalam pembelajaran biologi di kelas. uji coba terbatas menunjukkan respon siswa yang sangat baik ketika mereka belajar dalam kelas berbasis inkuiri terbimbing. Guru dapat memanfaatkan bahan ajar yang dikembangkan untuk memperbaiki proses pembelajarannya di dalam kelas. Penelitian tahap selanjutnya di masa depan dapat menggunakan bahan ajar yang dikembangkan untuk melihat efektivitas penggunaanya.

\section{DAFTAR PUSTAKA}

Adnan, \& Bahri, A. (2018). Beyond effective teaching: Enhancing students' metacognitive skill through guided inquiry. In Journal of Physics: Conference Series (Vol. 954, p. 12022). https://doi.org/10.1088/1742-6596/954/1/012022

Ango, M. L. (2002). Mastery of science process skills and their effective use in the teaching of science: an educology of science education in the nigerian context. Online Submission, 16(1), 11-30.

Ariyanti, S., Fajaroh, F., \& Sutrisno. (2013). Pengembangan bahan ajar Buffer Solution berbasis inkuiri terbimbing. Universitas Negeri Malang. Retrieved from http://karyailmiah.um.ac.id/index.php/kimia/article/view/25916

Ash-Shiddieqy, M. H., Suparmi, A., \& Sunarno, W. (2018). The effectiveness of module based on guided inquiry method to improve students' logical thinking ability. In Journal of Physics: Conference Series (Vol. 1006, p. 12001). https://doi.org/10.1088/1742-6596/1006/1/012001

Boddy, N., Watson, K., \& Aubusson, P. (2003). A trial of the five Es: a Referent model for constructivist teaching and learning. Research in Science Education, 33(1), 27-42. https://doi.org/10.1023/A:1023606425452

Damopolii, I., Hasan, A., \& Kandowangko, N. (2015). Pengaruh strategi pembelajaran inkuiri bebas dimodifikasi dan kemampuan memecahkan masalah terhadap keterampilan proses sains mahasiswa pada Praktikum Fisiologi Tumbuhan. Pancaran Pendidikan, 4(3), 191-200. Retrieved from http://pancaranpendidikan.or.id/article/view.php?id=91

Damopolii, I., Nunaki, J. H., Nusantari, E., \& Kandowangko, N. Y. (2018). Designing Teaching Material Oriented Towards Inquiry-Based Learning in Biology. In Mathematics, Informatics, Science, and Education International Conference (MISEIC 2018). Atlantis Press. https://doi.org/10.2991/miseic-18.2018.1 


\section{Formatif: Jurnal Ilmiah Pendidikan MIPA}

Vol. 9, No. 1, Maret 2019, pp. 59-70

p-ISSN: 2088-351X

e-ISSN: 2502-5457

DOI: http://dx.doi.org/10.30998/formatif.v9i1.2884

Damopolii, I., Nunaki, J. H., \& Supriyadi, G. (2018). Effect of problem solving learning model on students achievement. Journal of Education Research and Evaluation, 2 (1), 1-9. https://doi.org/10.23887/jere.v2i1.12558

Damopolii, I., Yohanita, A. M., Nurhidaya, N., \& Murtijani, M. (2018). Meningkatkan keterampilan proses sains dan hasil belajar siswa melalui pembelajaran berbasis inkuiri. Jurnal Bioedukatika, 6 (1). https://doi.org/10.26555/bioedukatika.v6i1.8029

Fadilah, S. I., Kardi, S., \& Supardi, Z. A. I. (2017). Pengembangan perangkat pembelajaran biologi berbasis inkuiri materi sistem ekskresi manusia untuk melatih keterampilan berpikir kritis dan kerjasama siswa SMA. JPPS (Jurnal Penelitian Pendidikan Sains), 5(1), 779-787.

Gillies, R. M., Nichols, K., Burgh, G., \& Haynes, M. (2012). The effects of two strategic and meta-cognitive questioning approaches on children's explanatory behaviour, problem-solving, and learning during cooperative, inquiry-based science. International Journal of Educational Research, 53, 93-106. https://doi.org/10.1016/j.ijer.2012.02.003

Hadi, S. A., Susantin, E., \& Agustini, R. (2018). Training of students' critical thinking skills through the implementation of a modified free inquiry model. Journal of Physics: Conference Series, 947, 12063.

Isrianto, P. L. (2016). Pembelajaran inkuiri melalui bertanam limbah sayuran untuk mengembangkan sikap ilmiah mahasiswa Pendidikan Biologi UWKS pada mata kuliah bercocok tanam. JINoP (Jurnal Inovasi Pembelajaran), 2 (2), 407-416. https://doi.org/10.22219/jinop.v2i2.3279

Kahar, M. S. (2018). Motivation analysis learning in the implementation of physics practicum. Formatif: Jurnal Ilmiah Pendidikan MIPA, 8(1), 1-6. https://doi.org/10.30998/formatif.v8i1.2304

Lameras, P., Petridis, P., Torrens, K., Dunwell, I., Hendrix, M., \& Arnab, S. (2014). Training science teachers to design inquiry-based lesson plans through a serious game. In Proceedings of the Sixth International Conference on Mobile, Hybrid and Online Learning (pp. 86-91). Retrieved from http://www.iaria.org/conferences2014/eLmL14.html

Lati, W., Supasorn, S., \& Promarak, V. (2012). Enhancement of learning achievement and integrated science process skills using science inquiry learning activities of chemical reaction rates. Procedia-Social and Behavioral Sciences, 46, 4471-4475.

Lawshe, C. H. (1975). A quantitative approach to content validity 1. Personnel Psychology, 28(4), 563-575.

Lepiyanto, A., \& Pratiwi, D. (2015). Pengembangan bahan ajar berbasis inkuiri terintegrasi nilai karakter peduli lingkungan pada materi ekosistem. Bioedukasi, 6 (2), 143-147. https://doi.org/10.24127/bioedukasi.v6i2.344

Lesmana, S. H., Lestari, I., \& others. (2015). Pengembangan Bahan Ajar Berbasis Inkuiri Materi Zat Aditif Kelas VIII SMP Negeri Se-kota Pontianak. Jurnal Pendidikan Dan Pembelajaran, 4 (11), 1-13. $\quad$ Retrieved from http://jurnal.untan.ac.id/index.php/jpdpb/article/view/12505

Loyens, S. M. M., \& Gijbels, D. (2008). Understanding the effects of constructivist learning environments: Introducing a multi-directional approach. Instructional Science, 36 (56), 351-357. https://doi.org/10.1007/s11251-008-9059-4

Mayasari, F., Raharjo, \& Supardi, Z. A. I. (2018). The development of inquiry learning materials to complete content life system organization in junior high school students. Journal of Physics: Conference Series, 947, 12034. 
Formatif: Jurnal Ilmiah Pendidikan MIPA

Vol. 9, No. 1, Maret 2019, pp. 59-70

p-ISSN: 2088-351X

e-ISSN: 2502-5457

DOI: http://dx.doi.org/10.30998/formatif.v9i1.2884

Moustafa, A., Ben-Zvi-Assaraf, O., \& Eshach, H. (2013). Do junior high school students perceive their learning environment as constructivist? Journal of Science Education and Technology, 22(4), 418-431. https://doi.org/10.1007/s10956-012-9403-y

Nisa, E. K., Koestiari, T., Habibbulloh, M., \& Jatmiko, B. (2018). Effectiveness of guided inquiry learning model to improve students' critical thinking skills at senior high school. Journal of Physics: Conference Series, 997, 12049.

Polit, D. F., Beck, T., \& Owen, S. V. (2007). Focus on research methods is the CVI an acceptable indicator of content validity. Res Nurs Health, 30, 459-467. https://doi.org/10.1002/nur.20199

Rukmana, D. (2018). Integration of learning cycle stage with inquiry labs method in learning physics to improve cognitive ability and science process skills of high school student. Formatif: Jurnal Ilmiah Pendidikan MIPA, 8 (2), 91-100. https://doi.org/10.30998/formatif.v8i2.2336

Sadeh, I., \& Zion, M. (2009). The development of dynamic inquiry performances within an open inquiry setting: A comparison to guided inquiry setting. Journal of Research in Science Teaching, 46(10), 1137-1160. https://doi.org/10.1002/tea.20310

Suwono, H., Susanti, S., \& Lestari, U. (2017). Guided Inquiry Facilitated Blended Learning to Improve Metacognitive and Learning Outcome of High School Students. In Journal of Physics: Conference Series (Vol. 824, p. 12068).

Tanner, K., \& Allen, D. (2004). Approaches to biology teaching and learning: learning styles and the problem of instructional selection-engaging all students in science courses. Cell Biology Education, 3(4), 197-201. https://doi.org/10.1187/cbe.04-070050

Thiagarajan, S., Semmel, D. S., \& Semmel, M. I. (1974). Instructional development for training teachers of exceptional children. Indiana: Center for Innovation in Teaching the Handicapped.

Trna, J., Trnova, E., \& Sibor, J. (2012). Implementation of inquiry-based science education in science teacher training. Journal of Educational and Instruction Studies In the World, 2 (4), 199-206.

Wagh, A., Cook-Whitt, K., \& Wilensky, U. (2017). Bridging inquiry-based science and constructionism: Exploring the alignment between students tinkering with code of computational models and goals of inquiry. Journal of Research in Science Teaching, 54(5), 615-641. https://doi.org/10.1002/tea.21379

Yang, I., Park, S., Shin, J., \& Lim, S. (2017). Exploring korean middle school students' view about scientific inquiry. Eurasia Journal of Mathematics, Science and Technology Education, 13 https://doi.org/10.12973/eurasia.2017.00765a 
Formatif: Jurnal Ilmiah Pendidikan MIPA

Vol. 9, No. 1, Maret 2019, pp. 59-70

p-ISSN: 2088-351X

e-ISSN: 2502-5457

DOI: http://dx.doi.org/10.30998/formatif.v9i1.2884

Halaman ini disengaja kosong 